\title{
Security education as a practical dimension of implementing sustainable development concept
}

\author{
Aleksander Sapiński * A; Ewelina Mączka ${ }^{\text {B }}$; Anna Nastuła ${ }^{\text {C }}$ \\ A Bielsko-Biała School of Finance and Law, Poland \\ ${ }^{B}$ University of Warmia and Mazury in Olsztyn, Poland \\ c Military University of Technology, Poland
}

Received: August 17, 2020 | Revised: August 27, 2020 | Accepted: August 31, 2020

DOI: $10.33445 /$ sds.2020.10.4.13

\begin{abstract}
The purpose of this article is to illustrate the fact that it is a combination of safety and sustainability. For a better understanding of the essence of the subject matter, the general issues forming sustainable development and the objectives of security education as a transmitter between generations are presented. The key factors of education for security arise from sustainable development objectives. The concept of education for security cannot be tantamount to the anticipated reduced curricula in schools. The concept of security must be promoted not only as one of human needs but as an indispensable determinant of development and vice versa. In order to better understand the message of this text, a study has been carried out on safety education programmes at various levels of education in the European Union. The whole consideration has been contextualised on the basis of an analysis of written sources concerning the state's internal security as and when it comes to global security. Taking into account the significant role of security in the proper implementation of the concept of sustainable development gives sense to the implementation of individual sustainable development objectives in relation not only to global but also regional as well as local conditions.
\end{abstract}

Key words: security education, the essence of security, sustainable development, CSR.

\section{Introduction}

Education and the need to discover the new has always been at the heart of the progress of civilization. Understanding the important role of education today is a change in the understanding of reality and the states through which it can be described and studied. Many decades of imposing ideological concepts and instilling their legitimacy with the help of the state apparatus in the countries of the Eastern Bloc, and until 1990 also in the countries of Central and Eastern Europe mixed in this sphere of influence, it seems justified to adopt some principles of Gestalt or non-directive pedagogy [1] for the sake of education for the security of sustainable development goals. In the human needs pyramid proposed by Abraham Maslov
[2], safety is one of the essential needs in human life. However, this need for safety is about:

feeling threatened, avoiding the threat, eliminating the threat.

However, understanding the need for security as such does not give a complete picture of the possibilities for the State, institutions and individuals to achieve sustainable development objectives. Creating the security that will be linked to sustainable development objectives requires a broader view of social and environmental issues. In this context, the division of security needs proposed by Waldemar Kitler [3] seems important:

the need for public safety and order,

\footnotetext{
* Corresponding author: Bielsko-Biała School of Finance and Law, Poland, Research assistant, Faculty of Law and Social Sciences, e-mail: olek.sapinski@interia.pl, ORCID: 0000-0002-3326-2387
} 
the need for universal security,

the need for health protection and sanitary and epidemiological safety,

the need for environmental protection and waste management,

the need to protect cultural heritage and national identity,

the need for economic security,

the need for education and upbringing,

the need for national security.

In the literature you can find a description of these needs, which groups them as determinants of universal security, also called citizen's security [3]. The concept of universal safety and the system it creates is very clear in the literature because it is described as a set of targeted and hierarchical legal norms that create tools for the state apparatus to protect citizens' goods and protect the economy and the interests of the state. The hierarchy of the system means that depending on the level it has comparable possibilities and important for the whole, as in the case of a pyramid, not only the top is important but also the base. The bond of the universal security system is responsibility, which, according to the dictionary definition, is the sense of responsibility for one's own actions [4]. The sense of responsibility is a key factor of success because a person aware of his actions understands that he is responsible not only for himself. Responsible behavior towards the concept of sustainable development can be presented as the continuity of human activity in the past, present and future in relation to oneself and other people. Therefore, the idea of civil security should be recognized as a process that is led through supervision and corrections in order to improve the already existing activities and generate new sub-processes in order to ensure a constant and unchanging quality of meeting the need for security for people on a macro and micro level. Changes in the perception of security needs result from the following factors:

states of habit and mentality of citizens,

dynamics of introduced social changes,

civil liberties,

the possibility of personal development and the lack of threat to your development through the provisions of state law,

increasing social diversity and the diversity of life choices,

standard of living and access to medical and educational services,

the possibility of influencing the environment and society,

Table 1 - Proposition of the division of security needs of modern man.

\begin{tabular}{|c|c|}
\hline "Sacred" needs & "Profane" needs \\
\hline $\begin{array}{l}\text { 1. intimate life zone and the delicate secrets of life } \\
\text { hidden from the world }\end{array}$ & 1. appearances of everyday life \\
\hline $\begin{array}{l}\text { 2. problems of family life, internal dilemmas and } \\
\text { social maladjustments }\end{array}$ & $\begin{array}{l}\text { 2. the possibility of externalizing the frustration } \\
\text { resulting from one's own failures by blaming others } \\
\text { for it. }\end{array}$ \\
\hline $\begin{array}{l}\text { 3. making your own choices without the judgment of } \\
\text { others }\end{array}$ & 3. preferred social and cultural roles. \\
\hline 4. securing the truth about oneself & 4. falsifying one's own image of the world \\
\hline
\end{tabular}

Source: autohors own elaboration.

Many other examples of determinants could be enumerated, taking into account the extensive literature on the subject, media reports or the practice of everyday life. In multicultural societies, such as the European Union countries and the neighboring countries, the perception of the need for security has changed many times under the influence of the 
politics of governments or the European Union. It would seem that certain elements of creating needs arise not so much from human needs as from trends and fashions that prevail in the economic market and the all-encompassing social media at a given time. The lives of many people can be divided into the sacred and the profane. However, it is not a traditional understanding of these phrases [5].

The above-mentioned examples and the division into the sphere of the sacred and profarnum of multiple needs for human safety in the realities of the modern world show a large dissonance between human needs and a certain problem in finding the right spheres requiring protection and development [6]. The division into the spheres of the sacred and the profane thus highlights the differences in the gradation of various security needs that arise in the modern world. Part of the safety needs arise from the emerging new human awareness and

\section{Material and Method}

In a turbulent world, many processes take place with irreversible consequences, which often have consequences not only for one but also for many next generations. Security is an interdisciplinary science which penetrates many fields of knowledge with its research interests. Research interdisciplarity results not only from the use of different research methods, but also from the compatibility of the information exchange planes obtained during the research. An important goal of conducting research is, therefore, the lack of reliable knowledge, analyzes and conclusions on a specific topic [8], which becomes a starting point for scientific research. Therefore, this article has been written to answer the following research questions:

1. Is there a relationship between meeting security needs and the goals of sustainable development?

\section{Results and discussion}

Conducting educational activities in schools is a natural and main process of the activity of educational institutions around the world. It is important in education that the message of the changes in civilization. However, there are some groups of selected social groups created for the needs of pseudo-economic development. Therefore, many artificially created needs pose a threat to potential people who want to protect themselves against them. It can therefore be concluded that the artificial creation of security needs in the modern world is becoming a kind of dark side of the security business. An important fact of the considerations on this topic may be the statement that the security needs located in the profane zone may therefore be the generatorm of other major problems with security not only individual but also collective. Considering all the threats posed by the security needs of modern man, one should agree with the statement by Leszek Korzeniowski that security is a social good [7]. However, in the research he has carried out, he presents different views on the issue of security depending on the local, regional or global scale.

2. What is the importance of education in the area of security for the implementation of the sustainable development goals?

3. Which of the goals of sustainable development are most closely related to the needs of security?

4. Which of the goals of sustainable development has the most significant impact on the practical implementation of security needs?

For the needs of the above questions, the authors carry out a critical literature search, analysis of research reports and observation of social life. The study also covered didactic materials and core curricula, which determine the transfer of material during classes in education for safety at various educational levels in Poland. Education at selected educational levels is consistent with the qualification framework adopted within the European Union and its educational standards.

material is reliable, not ideological, and therefore it may be false. As Adolf E. Szołtysek writes, "the new educational order introduces the definition of man, humanity, personality and 
behavior, values and attitudes, culture and education. (...) Within the new educational order there is room for socialist ideologies and the second is a technical operation. The new educational order deals with the implementation of ideology into school curricula and socialist education. In the meantime, the system was changed, but the mechanism of ideologization of education remained the same, but there was a change of signs" [9]. The above quotation introduces a reflection that shows how easy it is to distort the transfer of knowledge in education. In the case of education for safety, this could have catastrophic consequences in the future.

The very concept of education for security is not a new concept introduced by the school subject, but was already the subject of consideration among scholars over 20 years ago [10]. Considering the issue of security needs in the sphere of public life seems to be, for a long time, downplayed in relation to other activities. However, safety education in an intergenerational and lifelong learning framework should be provided. Analyzing the goals of education and the effects of the implementation of school activities in the subject of education for safety indicates that it is limited to the defense and pro-health aspects of first aid [11]. The general requirements include such content as [12]:

1. Knowledge of the state's defense structure.

The student distinguishes between the state's defense structures, understands their role and knows the forms of fulfilling defense duties by administrative bodies and citizens.

2. Preparation for emergency situations.

The student knows the rules of conduct in the event of a threat to life, health or property; knows the principles of planning and organizing activities.

3. III. Mastering the rules of first aid.

The student knows how to provide first aid to the injured in various life and health-threatening conditions.

Despite the fact that the topics discussed during the classes introduce elements of the environment, economy, biology and chemistry, as well as security and policy systems, it does not fully implement the objectives of the concept of sustainable development. In 2015, the UN General Assembly adopted resolutions establishing the objectives of sustainable development for the coming years, which can be described as follows [13][14]:

1. Eradicate poverty in all its forms worldwide;

2. Eliminate hunger, achieve food security and better nutrition, and promote sustainable agriculture;

3. Ensure healthy life for all people of all ages and promote well-being;

4. Providing quality education for all and promoting lifelong learning;

5. Achieving gender equality and the empowerment of women and girls;

6. Providing all people with access to water and sanitation through the sustainable management of water resources;

7. Providing everyone with access to sources of stable, sustainable and modern energy at an affordable price;

8. Promoting stable, sustainable and inclusive economic growth, full and productive employment and decent work for all people;

9. Building a stable infrastructure, promoting sustainable industrialization and supporting innovation;

10. Reducing inequalities within and between countries;

11. Make cities and human settlements inclusive, safe, resilient and sustainable;

12. Ensuring sustainable consumption and production patterns;

13. Take urgent action to combat climate change and its consequences;

14. Conserving oceans, seas and marine resources and using them in a sustainable manner;

15. Protect, restore and promote the sustainable use of terrestrial ecosystems, manage forests sustainably, combat desertification, halt and reverse soil degradation, and halt biodiversity loss;

16. Promoting a peaceful and inclusive society, ensuring access to justice for all, and 
building effective, accountable and inclusive institutions at all levels;

17. Strengthen the means of implementation and revitalize the global partnership for sustainable development.

From the point of view of security science, the above objectives can be divided into three groups:

- goals that ensure the safety and health development of modern man and future generations,

- goals ensuring the safety of the development of the human environment,

- goals ensuring climate security.

These goals largely coincide with the Millennium Goals set by the United Nations on this subject, but in their present form they are more accurate and propose a wider spectrum of human life on Earth. The grouping of goals of sustainable development in relation to safety should be accessed through the prism of subdisciplines of safety science, which are lacking in the area of education for safety as a subject. It is obvious that some issues important for the goals of sustainable development are realized in common schools also in other school subjects, however, many times young people will not associate these issues with their security needs. This raises the problem of effective education $n$ for security. The problem of the program itself is not the biggest one, because it is possible to modify it. The main problem may be the mentality of educated people and, according to the principle of life-long learning, the age of educated people. Closing education for security within school walls or in subsequent stages of life within the walls of universities and defense units causes certain security processes to be put to sleep. Therefore, the most important of the objectives of sustainable development become partnerships for sustainable development, i.e. goal 17. This is because both in school conditions, where cooperation and partnership are possible through project activities or practical training outside the school. Lack of cooperation, especially in the field of safety, makes the individual lose his or her herd sense and does not increase his or her competence to react, communicate or accept criticism of his or her ideas. In the framework of partnerships for sustainable development among people from outside school age, projects and social activities can be carried out with the aim of achieving this:

- protection of human rights and employee rights,

- protection of natural goods,

- ergonomic use of resources at work and at home,

- corporate social responsibility,

- security in times of peace and ways of maintaining it,

- security of economic transactions,

- security in cyberspace, especially in ICT systems responsible for banking and personal data.

Security Partnerships in the area of sustainable development are aimed at maintaining the fluidity of activities carried out in peacetime for the preservation of peace and the development of civilization progress, which will manifest itself not only in increasing the involvement of technology, but also in the issues of multifaceted human protection. A large part of the population, in different age groups, may seem to be lost in terms of their personal and state development. This is due to a lack of trust in the state or a lack of competence to assess the risks that their life decisions may entail. Many times, people use beliefs, stereotypes and patterns when making decisions. It can therefore be said that myths and legends prevail over a sober judgment of the situation when it comes to meeting security needs. In the case of far-reaching goals of sustainable development, which works like social programming. The lack of understanding of the sense and legitimacy of securing for oneself and for other goods defined in the concept of sustainable development does not allow to achieve the assumed effects of this programming. 


\section{Conclusions}

The creation of needs has become a domain no longer only of human nature, but also an artificial action that brings with it more or less thoughtful and identified threats to man and even to the entire human population. Many times, human activity is foreseeable by means of appropriate analyses and by early and permanent education of people, which can operate on the principle of social conditionality programming in order to achieve a specific goal. However, such activities require deep reflection and respect for ethics and human decency, which is often lacking in many business processes related to defense or research in modern times. Providing security education in the formula of lifelong learning would become the most effective form of implementation of good social attitudes that would support the achievement of sustainable development goals and, more broadly, the development and survival of humanity. Man, in his nature learns things through intellectual and sensual cognition [15]. However, the realization of cognition can, through intellectual processes during education, reduce the harmful effects that sensory cognition could cause in terms of security needs. Examples include chemical reactions or deliberate "sensory search" by young people. Therefore, it is possible to propose practical changes to the scientific and educational concept through:

development and implementation of social programming in the field of security needs for the realization of sustainable development goals,

implementation of issues from broad-based safety sciences into the curriculum at various school stages,

promoting the reaction of thought then explore,

focusing lifelong learning programs on subliminal implementation of opportunities to meet security needs in social life in accordance with sustainable development goals,

developing new media communication techniques for the transmission of information to specific social groups,

increasing control over new social media and to create programs for their educational use for safety and sustainability purposes,

promoting the return to natural forms of coexistence on the planet through organic farming, healthy lifestyle, rational nutrition, promotion of sports competition,

Systematizing the legal status of corporate social responsibility as an issue of further education of adults for sustainable development in relation to their security needs.

The need for change in the area of security education for sustainable development is a priority task, because social changes occurring at a high pace often cause irreversible changes in the perception of the world. It is not possible to continue to exist on the planet when primitive human instincts prevail over intellectual solutions to disputes. Among the actions taken by the UN for the smooth implementation of sustainable development goals should be a proposal to enforce the implementation of these actions. Because their absence interferes with the possibility of the management process of the whole undertaking.

\section{References}

1. Śliwerski B.(2015) Współczesne teorie i nurty wychowania, Kraków: Impuls

2. Strelau J. (2007) Psychologia. Podręcznik akademicki Tom 2 Psychologia ogólna, Gdańsk: Gdańskie Wydawnictwo Psychologiczne

3. Ściborek, Z et. all.(2017) Bezpieczństwo wewnętrzne, Torun: Wydawnictwo Adam Marszałek
4. Aronson, et. all. (1997) Psychlogia społeczna. Serce i umysł. Poznań: Wydawnictwo Zysk i Ska.

5. Bianchi, P.G. (2009) Duchowość zarządzanie, Tyniec: Wydawnictwo Benedyktynów

6. Cupka, S. (2020) The stability of the world image in creating a global sense of security, ASEJ2/2020, DOI: 10.5604/01.3001.0014.3278 
7. Korzeniowski, L. (2017) Podstawy nauk o bezpieczństwie, Warszawa: Difin

8. Wziątek-Staśko, A. (2012) Diversity management, Warszawa: Difin

9. Szołtysek A.E. (2013) Filozofia edukacji, Kraków: Impuls

10. Elak, H (2017) Edukacja na rzecz bezpieczństwa w świetle nowej reformy oświaty [in] Obronność Zeszyty naukowe 3(23)/2017

11. Załącznik nr 4 do: rozporządzenia Ministra Edukacji Narodowej z dnia 23 grudnia 2008 r.w sprawie podstawy programowej wychowania przedszkolnego oraz kształcenia ogólnego w poszczególnych typach szkół (Dz. U. z dnia 15 stycznia 2009 Nr 4, poz. 17)

12. Podstawa programowa kształcenia ogólnego z komenatrzem, Edukacja dla bezpieczństwa Szkoła podstawowa, ORE, Warsawa 2016

13. www.un.org/sustainabledevelopment 14. pl.wikipedia.org/wiki/Cele_Zrównoważoneg o_Rozwoju_2030

15. Lenartowicz, P., Koszteyn J. (2012) Wprowadzenie do filozofii, Kraków: Petrus 